\title{
Correlation Between Hormonal Contraceptives Use and Age of Menarche with Breast Cancer Among Women in Indonesia: A Systematic Review
}

\author{
Nurmalia Ermi ${ }^{1}$ and Sudijanto Kamso ${ }^{2}$ \\ ${ }^{1}$ Postgraduate Student Faculty of Public Health, Universitas Indonesia, Depok, Indonesia \\ ${ }^{2}$ Faculty of Public Health, University of Indonesia, Depok, Indonesia
}

\section{Abstract}

Cancer is one of the leading causes of death worldwide. According to GLOBOCAN, International Agency for Research on Cancer 2012, it is known that breast cancer is cancer with the highest percentage of new cases, at $43.3 \%$, and percentage death due to breast cancer by $12.9 \%$. Although the incidence of breast cancer in Asia remains lower

Corresponding Author:

Nurmalia Ermi

nurmaliaermi92@gmail.com

Received: 21 December 2018

Accepted: 23 January 2019

Published: 28 February 2019

Publishing services provided by Knowledge E

(c) Nurmalia Ermi and Sudijanto Kamso. This article is distributed under the terms of the Creative Commons Attribution License, which permits unrestricted use and redistribution provided that the original author and source are credited.

Selection and Peer-review under the responsibility of the $3 \mathrm{rd}$ IMOPH \& the 1st YSSOPH Conference Committee. than in North America, Western Europe, and Oceania, the rates have been increasing rapidly during the past few decades, and Asian countries now account for $40 \%$ of breast cancer cases diagnosed worldwide. Southeast Asian countries have moderate rates for breast cancer, with a higher incidence of one in Indonesia. Breast cancer morbidity and mortality increased among Indonesian women. These increased rateswere associated with higher prevalence of breast cancer risk factors such as hormonal contraceptive use and age of menarche. The purpose of this study was to determine the correlation between hormonal contraceptives use and generation of menarche with breast cancer among women in Indonesia. This study used a systematic review made by PRISMA. Searching for literature sources through online databases such as Science Direct, JSTOR, and Proquest, additional records identified through Google Scholar by using relevant keywords adjusted by inclusion and exclusion criteria. Five studies included in this review. All studies discussed breast cancer among women in several regions in Indonesia. There was a significant correlation between hormonal contraceptives use and age of menarche with breast cancer among women in Indonesia. Women may be more careful in determining the duration of hormonal contraceptive use and avoiding a lifestyle that can accelerate menarche.

Keywords: Hormonal contraception, Age of menarche, Breast cancer, Indonesia

\section{Introduction}

G OPEN ACCESS deaths caused by the disease. According to the World Health Organization(WHO), 
cancer was one cause of death worldwide and an estimated 84 million people died from cancer in the period 2005 to 2015 [1].

According to GLOBOCAN, International Agency for Research on Cancer (IARC) 2012, it is known that breast cancer is cancer with the highest percentage of new cases, at $43.3 \%$, and percentage death due to breast cancer by $12.9 \%$ [2]. Breast cancer is a group of cells abnormally, and multiple growing in breast tissue and is the most common malignant disease found in the female group [3]. Breast cancer is a malignancy in breast tissue that can originate from the ductal epithelium or lobules [4].

In America, there are about 92/100.000 women with breast cancer, with 27/100.000 mortality or $18 \%$ of deaths found in women [4]. Although the incidence of breast cancer in Asia remains lower than in North America, Western Europe, and Oceania, rates have been increasing rapidly during the past few decades, and Asian countries now account for $40 \%$ of breast cancer cases diagnosed worldwide [5]. The incidence of breast cancer is higher in developed countries, but the mortality is around69\% in developing countries [6]. Southeast Asian countries have moderate rates for breast cancer, with a higher incidence of one in Indonesia [5].

Breast cancer is one of the most cancer types in Indonesia. Based on pathological based registration in Indonesia, breast cancer ranks first with a relative frequency of 18.6\%. Data of cancer in Indonesia in 2010, according to histopathological data; Cancer Registration Agency Association of Indonesian Pathology Specialists and Cancer Foundation Indonesia estimated the number of incidence in Indonesia is $12 / 100.000$ women. More than $80 \%$ of cases are found to be in an advanced stage [4].

Breast cancer morbidity and mortality increased among Indonesian women. In the Dharmais Cancer Hospital, the number of new cases and death from breast cancer has risen by four years in a row. In 2010, the number of new cases was 711 cases, 93 cases of them caused death. In 2011, the number of new cases was 769 cases, 120 cases of them caused death. In 2012, the number of new cases was 809 cases, 130 cases of them caused death. And by 2013, the number of new cases was 819.217 cases of them caused death. [7]. These increased rates associated with higher prevalence of breast cancer risk factors such as hormonal contraceptive use and age of menarche. This systematic review was conducted to determine the correlation between hormonal contraceptives use and generation of menarche with breast cancer among women in Indonesia.

\section{Methods}

This study used a systematic review made by prisma 2009. Source literature search began on 10 June 2017 by electronic data based through remote.lib.ui.ac.id/lib.ui.ac.id website. The author conducted searching on Science Direct, JSTOR, and Proquest, additional records identified through Google Scholar. Keywords are Hormonal Contraception AND Age of Menarche AND Breast Cancer AND Indonesia. The criteria inclusion in this study were Indonesian and English language, Indonesia state and the journal year is the last ten years published, starting from 2007 to 2017 . The criteria exclusion criteria are apart from the inclusion criteria. 
From Science Direct, it's obtained 12 journals, JSTOR 12 journals, Proquest 91 journals, and google scholar 1640 memoirs. Journals screen by years 2007-2017 was 850. After identification conducted initial screening by reading the titles and abstracts, it's obtained 20 journals, and 838 journals remove because of claim, state, variable and year which were not appropriate with the topic. In the eligibility phase, eight journals were reviewed to decide whether the journals could use and authors got five journals systematically for systematic review.

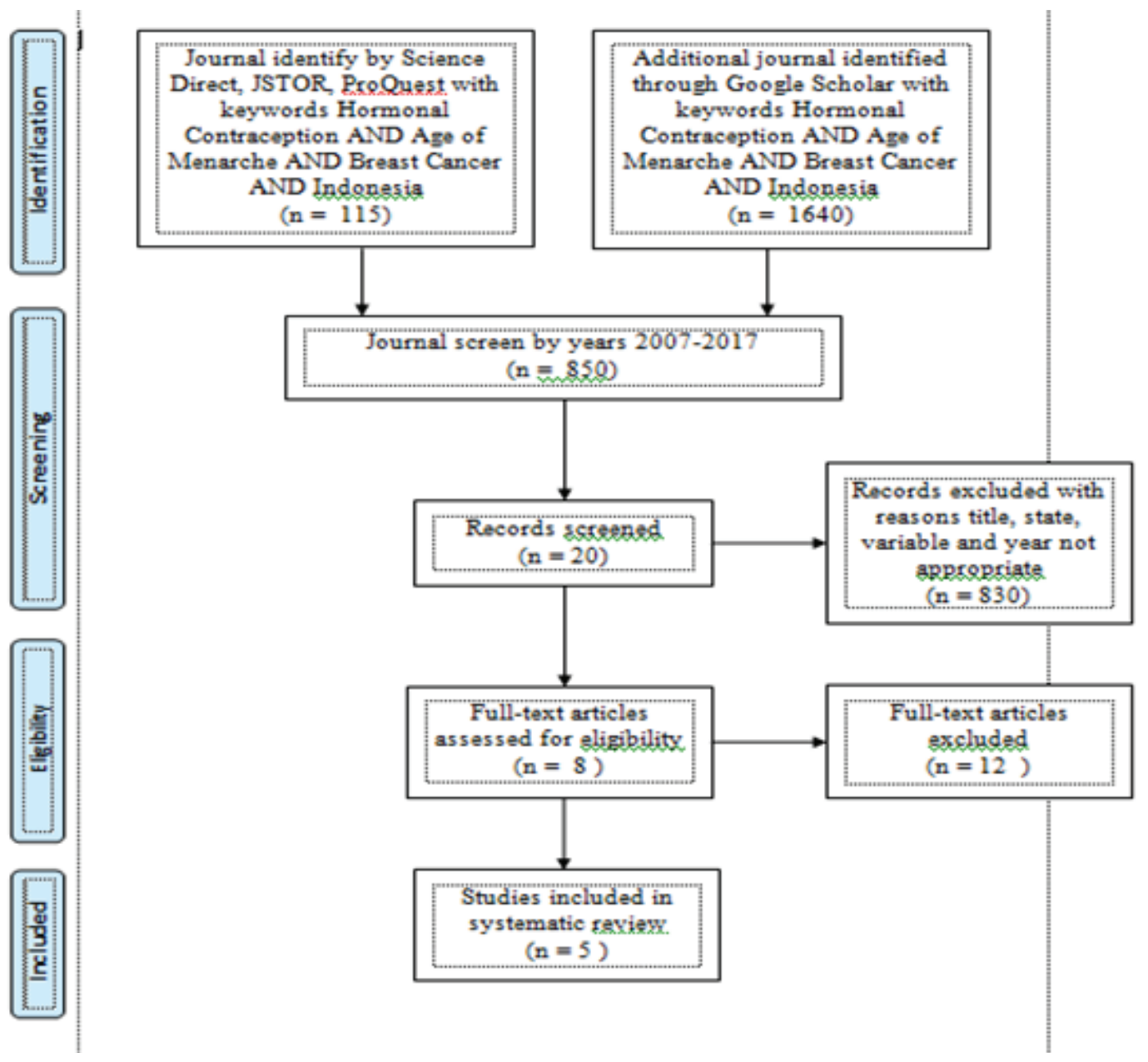

Figure 1: Systematic Review Flowchart.

\section{Results}

Five studies included in this review. All studies discuss breast cancer among women in several regions in Indonesia.

Based on research conducted by Dwi Kartika Rukmi and Rukmi Handayani (2014), risk factors related to breast cancer according to multivariable analysis were age of menarche $<12$ (OR: 15.84; Cl: 1.27-198.29; $\mathrm{p}=0.032$ ) and application of hormonal contraceptive (OR: 3.625; Cl: 1.02-12.93; $p=0.040$ ) [8]. 
The results of the study of Fitria Prabandari and Dyah Fajarsari (2016) found that there is a correlation between breast cancer and age of menarche with p-value 0,013 (OR: 21.242; Cl: 1.919-235.181) and there is a correlation between breast cancer and the application of hormonal contraceptive with p-value 0,041 (OR: 12.759; Cl: 1,108-146.874) [9].

Research by Gusti Ayu Triara Dewi and Lucia Yovita Hendrati (2015), the results of the analysis using binary logistic regression $(\alpha=5 \%)$ indicated that the use of hormonal contraceptive ( $p=0.028)$; OR: 3.266$)$ and age of menarche $(p=0.031$; OR: 3.492) has a significant correlation with the incidence of breast cancer in women at Dr. Soetomo Hospital [10].

Research by Harianto, Rina Mutiara, and Hery Surachmat (2015) with case-control research designs found that the use of combination contraception pills has the risk to have breast cancer 1,864 times compare with them who don't take that pills [11]. Marice Sihombing and Aprildah Nur Sapardin (2015) on the results of their research found that one of the dominant risk factors of breast tumor among women was the use of contraception with p-value 0.002 (OR: 3.63; Cl: 1.63-8.10) [12].

\section{Discussion}

\subsection{Correlation between hormonal contraceptives use and breast cancer}

Contraception is one effort that can select to prevent conception and pregnancy. Based on the method, contraception divided into simple contraceptives and modern contraceptives. Modern contraception divided into four processes, namely mechanical, hormonal, chemical, and operative techniques. Hormonal methods of pill, injection, or implant.

Use of hormonal contraceptives can increase the risk of breast cancer. Such hormonal contraceptives can be pills, combination pills, and mini-pills, injections, or implants or plants [13]. The risk of breast cancer incidence associated with long-term use of hormonal contraception.

The use of oral contraceptives over extended periods causes an increased risk of breast cancer. The increased risk of breast cancer also occurs in women who use hormone therapy, such as exogenous hormones. The exogenous hormone can cause an increased risk of breast cancer. The use of hormonal contraceptives can lead to increased exposure of the hormone estrogen in the body. There is an increase in exposure to the hormone estrogen that can trigger abnormal cell growth in certain parts, such as the breast.

\subsection{Correlation between age of menarche and breast cancer}

Women who have first menstruation at $<12$ years of age have a slightly higher risk of breast cancer than women who have first menstruation $>12$ years of age. Increased risk 

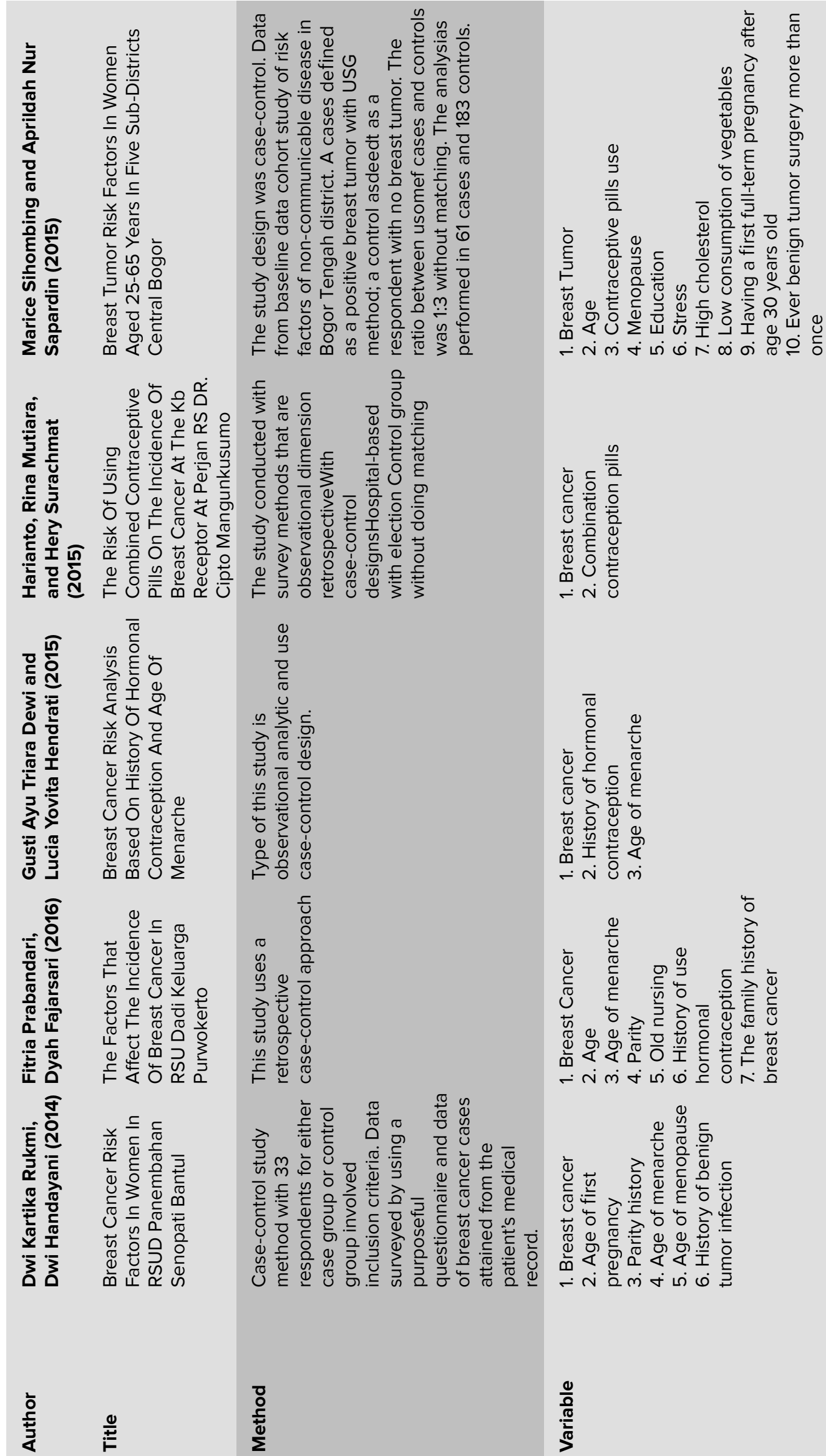


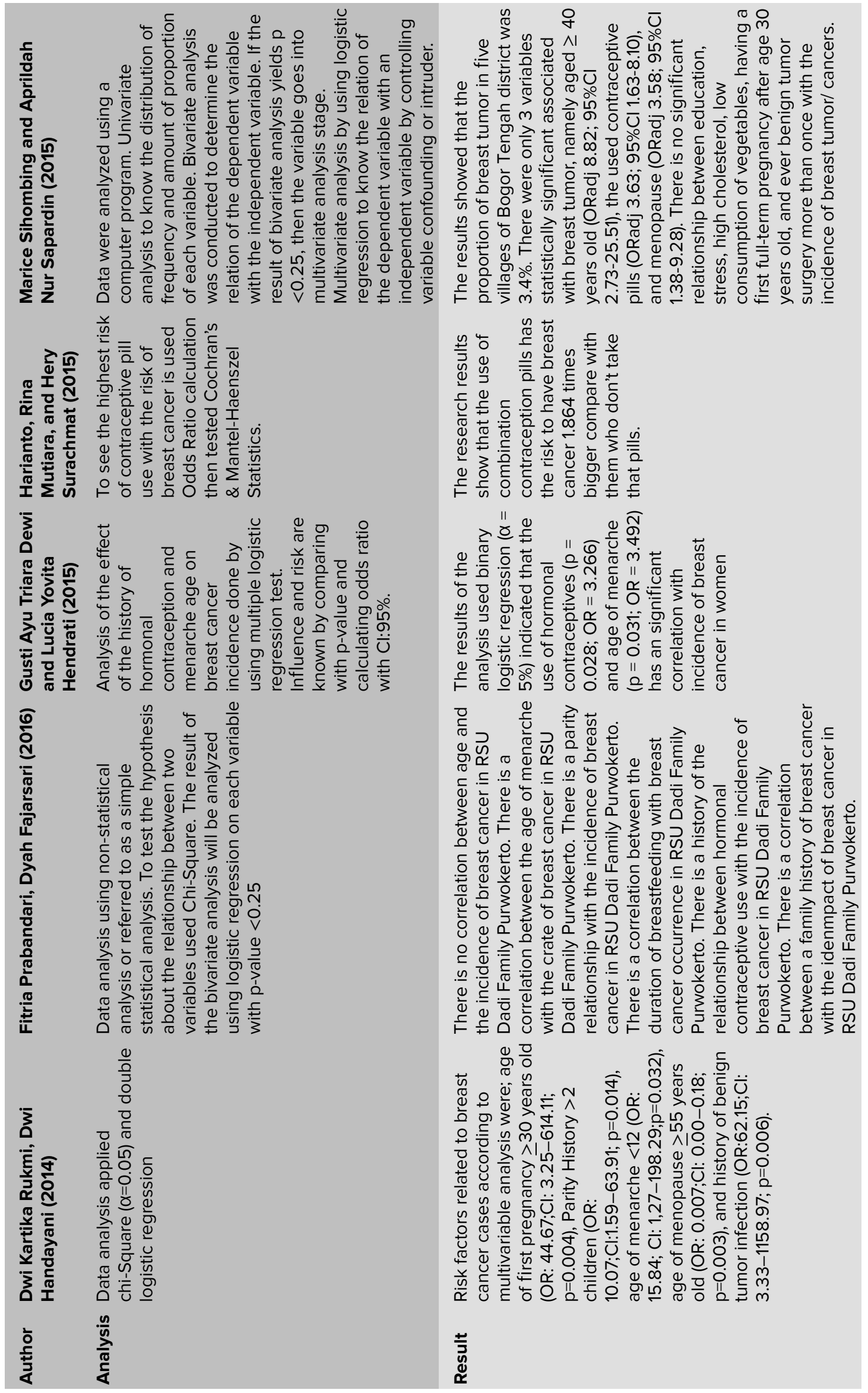




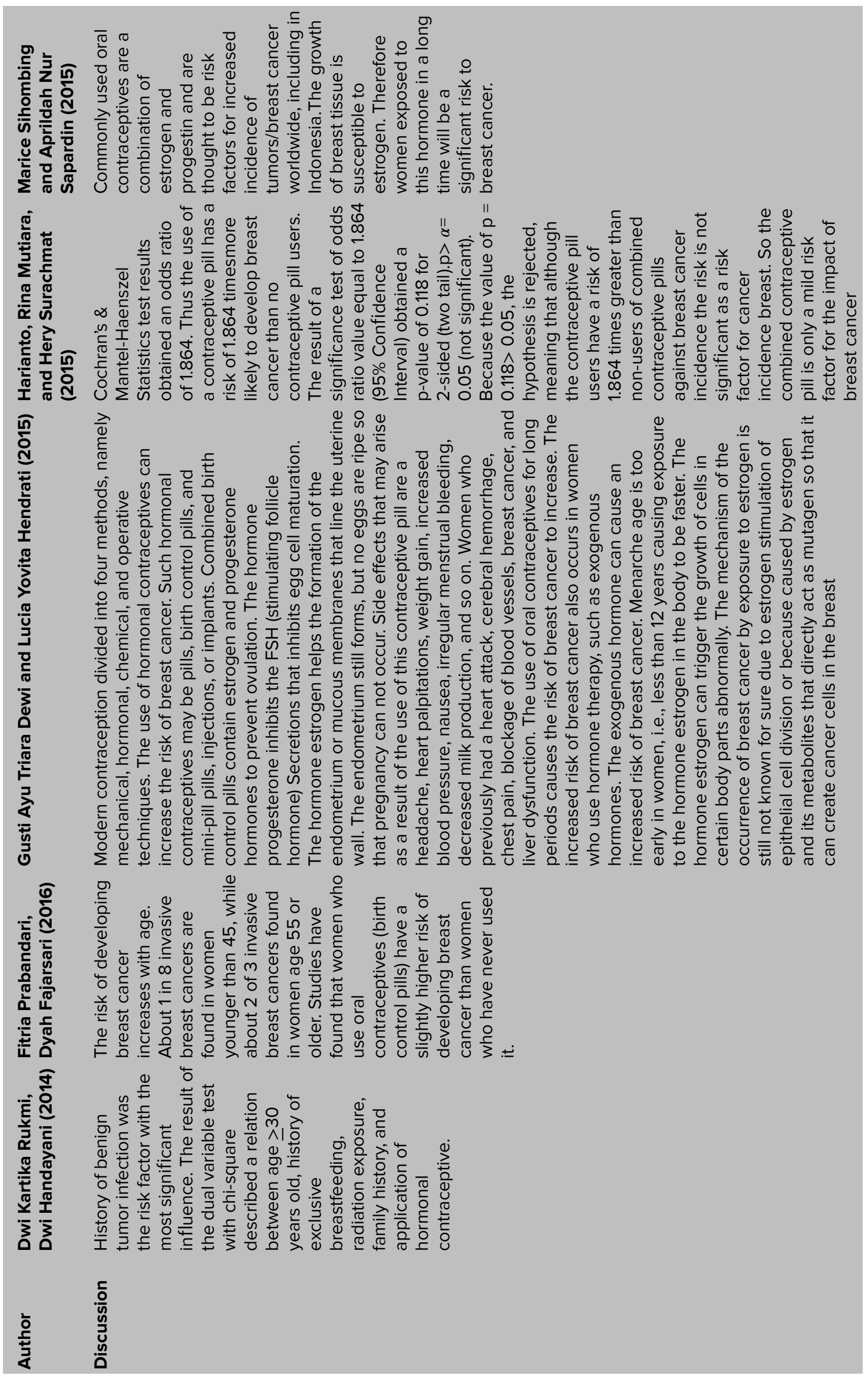




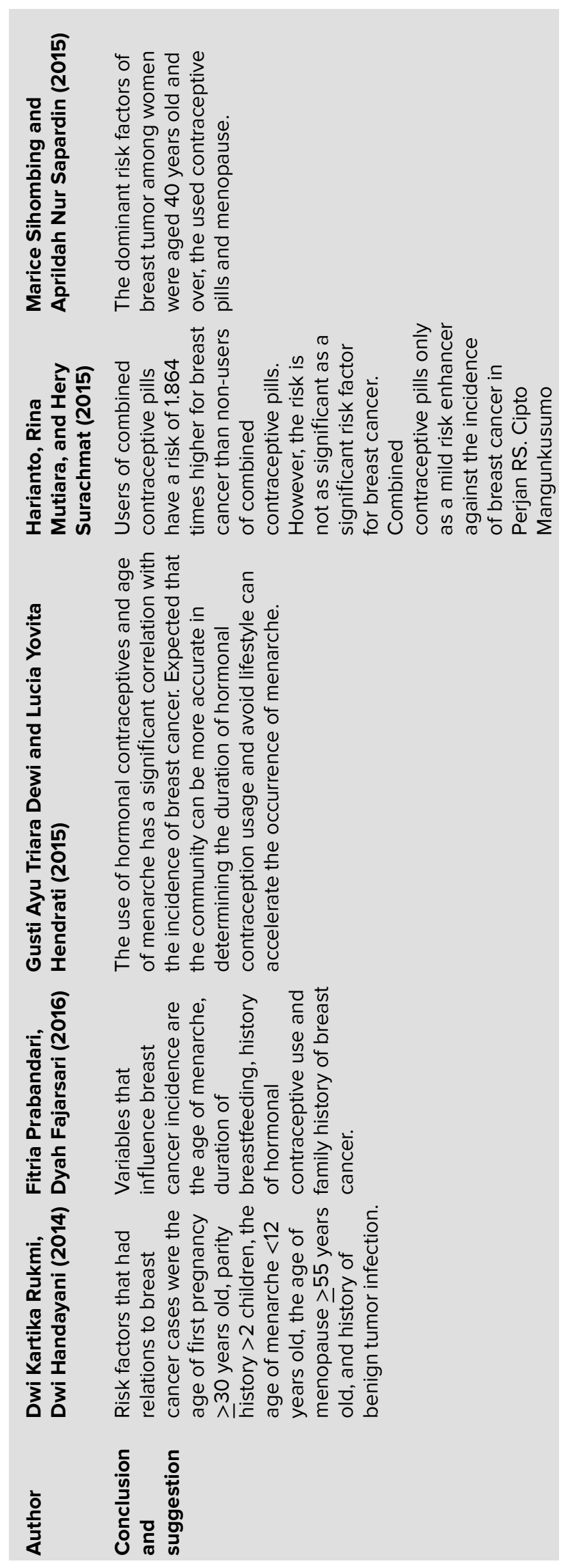


of breast cancer is due to the duration of estrogen exposure that is longer and slightly higher.

When a woman experiences her first period, the function of ovarian cycles that production of estrogen begins. The longer a woman is exposed, the higher the risk for breast cancer she gets. In addition to being presented, the regularity of the menstrual cycle also plays a role. The balance of the period describes the frequency of exposure, so the faster a woman gets a higher exposure compared to women whose regular menstruation is slower or has a long menstrual cycle [14].

Menarche age is too early in women, less than 12 years causing exposure to the hormone estrogen in the body to be faster. Estrogen hormone can trigger the growth of cells in certain parts of the body is not normal. The mechanism of the occurrence of breast cancer by estrogen exposure is still not known for sure due to estrogen stimulation of epithelial cell division or because of a cause by estrogen and its metabolites that directly act as mutagens that can cause cancer cells in the breast [15].

\section{Conclusion}

There is a significant correlation between hormonal contraceptives use and age of menarche with breast cancer among women in Indonesia. The longer the duration of hormonal contraceptive use, the higher the risk of breast cancer. Women who are more at risk of breast cancer are women with a first menstrual period of fewer than 12 years. Based on the systematic review, authors have a few suggestions: women may be more careful in determining the duration of hormonal contraceptive use, avoiding a lifestyle that can accelerate menarche, need to do early detection regularly with breast selfexamination and then followed by examination mammography every year, and need understanding of prevention efforts, early diagnosis, curative or palliative treatment and good rehabilitation efforts.

\section{Acknowledgment}

The online library University of Indonesia that has given access to the world's colossal database look for a systematic review

\section{Ethical approval}

No ethical approval

\section{Competing Interest}

No competing interest 


\section{References}

[1] Kementerian Kesehatan Republik Indonesia. Peringatan Hari Kanker Sedunia. Available from URL: http: //www.depkes.go.id/

[2] International Agency for Research on Cancer, World Health Organization. 2012. World cancer report. Available from URL: http://globocan.iarc.fr/

[3] American Cancer Society. Breast Cancer: What Is Breast Cancer. Available from URL: http://www. cancer.org/cancer/breastcancer/detailedguide/breast-cancer-what-is- breast-cancer, 2014.

[4] Kementerian Kesehatan Republik Indonesia. Panduan Penatalaksanaan kanker Payudara. Jakarta: Komite Penanggulangan Kanker Nasional Kementerian Kesehatan Republik Indonesia; 2017.

[5] Kim, Yeonju, Keun-Young Yoo, and Marc T Goodman. The difference in Incidence, Mortality, and Survival of Breast Cancer by Regions and Countries in Asia and Contributing Factors. Asian Pacific Journal of Cancer Prevention, Vol 16, 2015: 2857-2870

[6] World Health Organization. Breast Cancer: Prevention And Control. Available from URL http://www.who. int/cancer/en/

[7] Kementerian Kesehatan Republik Indonesia. Bulletin Jendela Data dan Informasi Kesehatan Situasi Penyakit Kanker. Jakarta: Pusat Data dan Informasi Kementerian Kesehatan Republik Indonesia; 2015.

[8] Rukmi, Dwi Kartika and Dwi Handayani. Breast Cancer Risk Factors In Women In RSUD Panembahan Senopati Bantul. Media IImu Kesehatan Vol.3, No.3, December 2014: 140-147

[9] Prabandari, Fitria and Dyah Fajarsari. The Factors That Affect The Incidence Of Breast Cancer In RSU Dadi Keluarga Purwokerto. Jurnal IImiah Kebidanan Vol. 7 No. 1 Edisi Juni 2016, him 105-118

[10] Dewi, Gusti Ayu Triara and Lucia Yovita Hendrati. Breast Cancer Risk Analysis Based On History Of Hormonal Contraception And Age Of Menarche. Jurnal Berkala Epidemiology, Vo.I 3, No.1 January 2015: 12-23

[11] Harianto, Rina Mutiara and Hery Surachmat. The Risk Of Using Combined Contraceptive Pills On The Incidence Of Breast Cancer At The Kb Receptor At Perjan RS DR. Cipto Mangunkusumo. Majalah IImu Kefarmasian, Vol. II, No. 1, April 2015: 84-99

[12] Sihombing, marice and Aprildah Nur Sapardin. Breast Tumor Risk Factors In Women Aged 25-65 Years In Five Sub-Districts Central Bogor. Jakarta: Pusat Teknologi Terapan Kesehatan dan Epidemiologi Klinik, Badan Penelitian dan Pengembangan, Kementerian Kesehatan Rl; 2015.

[13] Puspitasari, N. Metode Kontrasepsi. Surabaya: Departemen Biostatistika dan Kependudukan Fakultas Kesehatan Masyarakat Universitas Airlangga; 2008.

[14] Putri, N. Deteksi Dini Kanker Payudara. Yogyakarta: Aura Media; 2009.

[15] Sandra, Y. Melatonin and Breast Cancer. Majalah Kesehatan Pharma Medik a, Vol. 3. No.2, 2011: $286-$ 291 